\title{
Domino Sense Analogous Contradict Planning of A CMOS
}

\author{
Mohan Raj.R, Balaji.S, John Paul Praveen.A.
}

\begin{abstract}
The fundamental target of this paper comprises of the domino rationale way and checking path. A fast wide range parallel contradicts that accomplishes high working frequencies throughout an account pipeline segment demeanor utilizing just three undemanding redundant CMOS-rationale module types. The three essential module types are isolated by $D$ flip failure. The three element types are set in an exceedingly dull constitution in the tallying way and Domino Logic way. Enthusiastic domino rationale circuits are broadly utilized in present day computerized VLSI circuits. These dynamic circuits are utilized in superior structures. Along these lines simultaneously refreshing the tally state with a consistent deferral at all tallying way module regarding the clock edge. This construction is versatile to self-assertive portion counter widths utilizing just the three module types. The deferral counter is contained the underlying module admittance times only, three-info AND-entryway delay and a D-type flip-flop. The motivation behind the project is to diminish the Power utilization and CMOS Technology in the counter way and Domino rationale way by utilizing DSCH in Microwind Tool. The proposed Counter way is structured utilizing $0.10 \mu \mathrm{m}$ TSMC Digital cell library and its expended $0.215 \mathrm{~mW}$.

Keywords : CMOS Parallel counter design, Domino logic, Counter path..
\end{abstract}

\section{INTRODUCTION}

The analogous neutralize structural design enables lofty spring and diminutive devise time for ample contradict applications. Numerous applications are comprise of these various elementary operations [1]. To a great extent investigate focuses on resourceful contradict architecture propose and the design methodologies investigate tradeoffs flanked by operating frequency, power consumption, area necessities an intention relevance occupation. These Rapid analogous counters ascertain an assortment of applications for mathematics tasks that integrate neural systems and various situations off the atomic instruments computerized frameworks. The explanation highlights obligatory will disagree enormously relying on a specific early plan systems improved counter working recurrence by apportioning huge counters into numerous littler tallying modules, with the end

Revised Manuscript Received on August 22, 2019.

Mohan Raj.R Assistant Professor, Department of Electronics And Communication Engineering,, Bharath Institute of Higher Education and Research, Chennai, India. dspmohanraj@gmail.com

Balaji.S, Assistant Professor, Department of Electronics And Communication Engineering,, Bharath Institute of Higher Education and Research, Chennai, India. bala.sripathy@ gmail.com

John Paul Praveen.A, Assistant Professor, Department of Electronics And Communication Engineering,, Bharath Institute of Higher Education and Research, Chennai, India. johnpaul.embedded@gmail.com goal that modules of privileged hugeness (containing higher noteworthy bits) were empowered for all bits in all of the modules of lower noteworthiness (containing lower critical bits) soak. Instatements and spread postpones, for example, register burden time, AND rationale chain interpreting, and the half incremented segment delays down the middle adders directed working recurrence [2][3].

Each tallying module check authorize sign as to be legitimate AND of the express signals from all the past checking modules (all tallying modules of lower noteworthiness), along these lines prescaling timed modules of higher hugeness utilizing a low recurrence sign got from modules of lower importance. Because of these various pre scaling devise, the supreme working as repetition and was restricted by the incremented, DFF access time, and the AND door delay and where as the AND door postponement may perhaps conceivably be huge for huge unhurried counters because of colossal fan-in and fan-out parasitic segments.

Structure adjustments improved AND entryway postponement, and in this manner working recurrence, by redistribute the AND doors are to a littler fan-in and fan-out design isolated by hooks. Be that as it may, the disadvantage of this redistribution was expanded tally idleness.

Furthermore, because of the plan structure, this counter design acquired a sporadic VLSI format structure and brought about a huge zone overhead. The respite is sorted out as pursues area II examines proposed CMOS parallel counter plan. Segment III gives counter way. Area IV presents recreations consequences for counter way blended to a DSCH and Microwind apparatus. At last, finish up and give future bearings in segment $\mathrm{V}$ [4][5].

\section{CMOS PARALLEL COUNTER DESIGN}

Subsequently circumstances transitions is the including modules of privileged implication are enabled on the various clock sequence preceding the state evolution using incentive commencing the domino logic alleyway [6].

1) A Single clock information triggers all tallying modules all the while, bringing about a working recurrence free of contradict distance across. The all out basic way delay (paying little respect to contradict width) is homogeneous at all the checking stages of various equivalent to the mix of the entrance time of a 2-bit toting up module [7].

2) A analogous contradict engineering use seclusion, to empowers elevated malleability and reusability, and in this way empowers short plan time for wide contradict applications.

Whereas the design is to be made out of the three elementary. So, these three module types are set in an exceptionally tedious formation in both of the tallying technique and the 
domino rationale ways, which will points of confinement restricted associations with just three sign (in this manner, fan-in $\leq 3$ and fan-out = 1 ) [8].

3) The contradict capitulate is in radix-2 portrayal so the check esteem can be perused with no extra rationale translating [9].

4) Unlike past analogous contradict structures that have tally latencies of a few cycles, contingent upon the counteract widths analogous counteract has no check dormancy, which will empowers the tally an incentive to be perused on-the-fly. The current parallel counter circuit dependent on a CMOS usage plot. It gives timing investigation and related equations. The respite is sorted out as pursues area II examines proposed CMOS parallel counter plan. Segment III gives counter way. The deferral counter is contained the underlying module admittance times only, three-info AND-entryway delay and a D-type flip-flop.

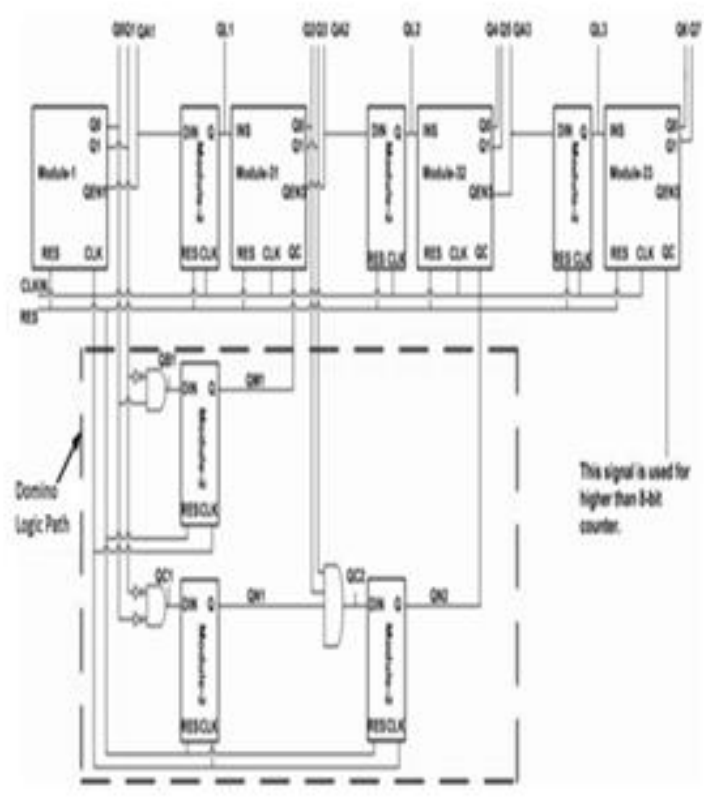

Fig.1.Parallel counter architecture

\section{A.Counting Path}

Module-1 Count will be started due to the function of D-flip flop. Module I consumes $0.101 \mathrm{~mW}$ power using $0.10 \mu \mathrm{m}$ Domino CMOS technology [10].[17][18[19][20]
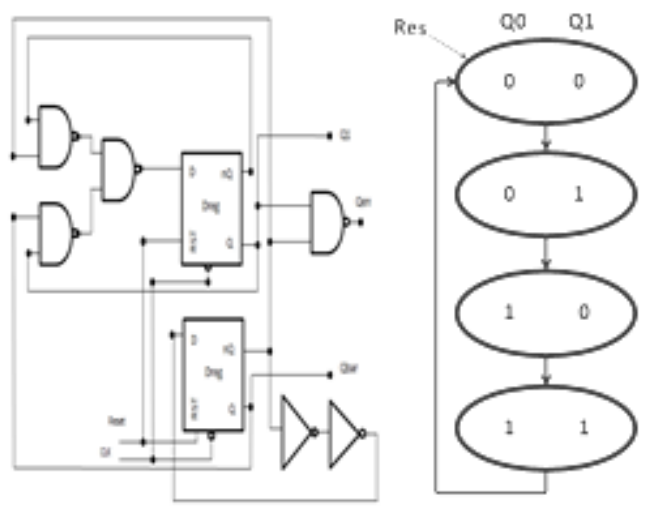

Fig.2. Module no 1 (a) Hardware Schematic and (b) state diagram

Module-2 the arrangement of module-2s in the checking way in which the indispensable to the oddity of our contradict constitution. Module-2s in the considering way act a pipeline connecting the module-1 and module-31 and between ensuing module-3S. The module-2s in the checking way accommodate setting off the module-3, empowering the module-2 to keep up a dependable postponement as opposed to sitting tight for the over stream undulating in a standard swell counter [11].

Module no 3 Module no $3 \mathrm{~S}$ is a analogous synchronous double 2-bit contradict those who check in empowered by INS. By utilizing Microwind device. On the off chance that INS $=1$ go to next stage. Generally INS $=0$ remain in current stage [12]. The Domino rationale gives the QC input. QEN3 interfaces with the resulting module no 2 DIN information and gives the one-cycle component. Module III devours $71.402 \mu \mathrm{W}$. Power utilizing $0.12 \mu \mathrm{m}$ Domino CMOS innovation.

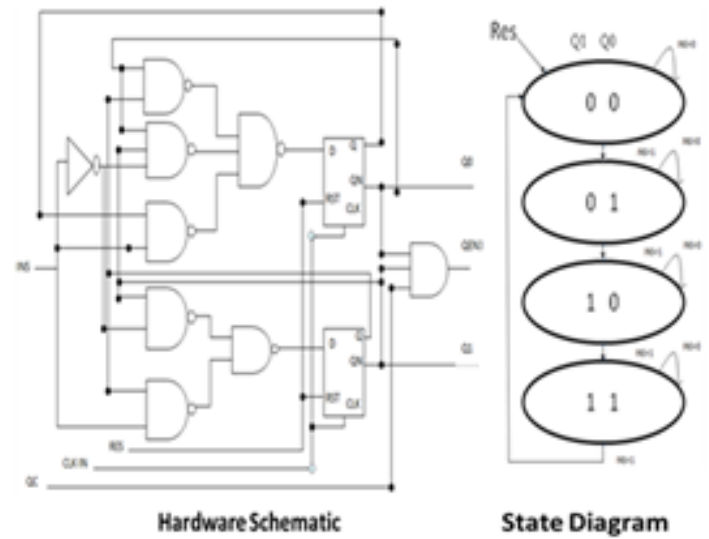

Fig.3. Module-3 (a) hardware schematic and (b) state diagram

\section{III.COUNTER PATH}

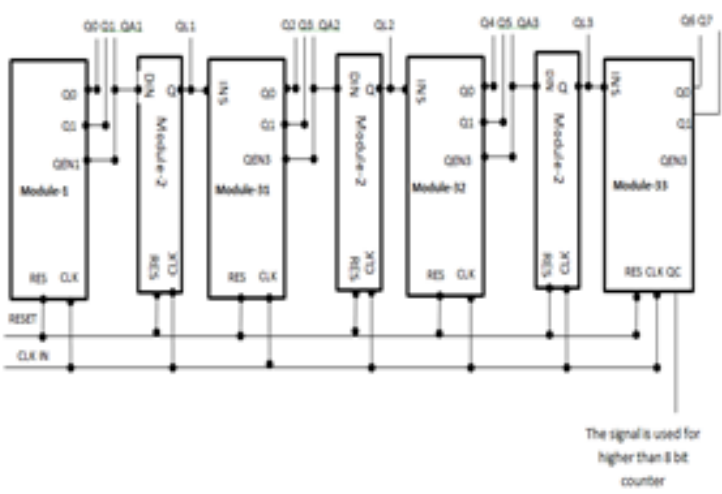

Fig.4. Counter Path

It comprise of three modules are Module 1, Module 2, Module3.A adaptable rapid parallel counter plan utilizing domino CMOS door rationale[13]. The counter structure rationale is involved just 2-bit tallying modules AND. Counter way expend less power contrast and static CMOS rationale and working at fast. Clock will be Triggered, Reset will be empower Condition. Yield is Q1-Q7, QA0-QA3, QL1-QL3.Counter Path have finished by utilizing microwsind apparatus. Decreased the Power 0.215mW [14]. 


\section{IV.RESULT DISCUSSION}

Module-1

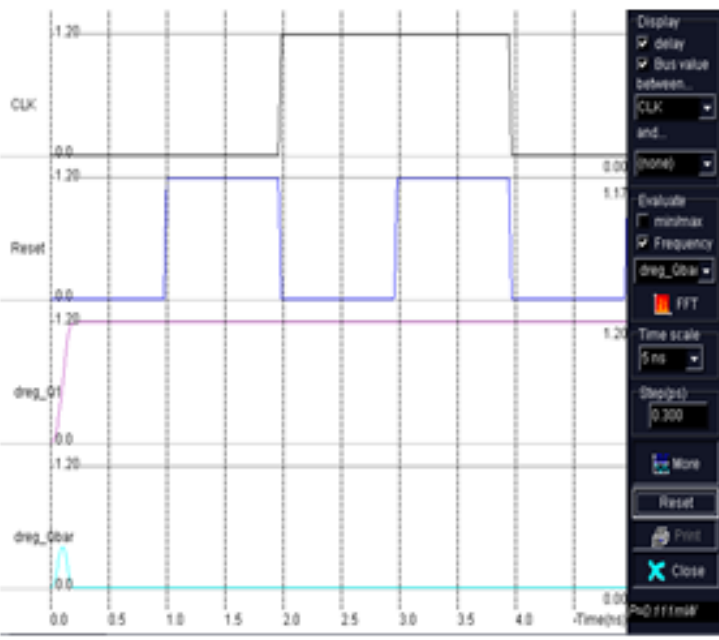

Fig.5. Simulation result for Module 1

Above figure, depicts Module 1. It comprises of three yields Q1, Qbar, and QEN1. Reset going to incapacitate condition. Tally will be begun because of the capacity of D-flip failure Clock activated, Q1, Qbar check (00, 01, 10, and 11) when RST has high, QEN will be high. Utilizing Microwind Layout Design of Module 1 as appeared in figure underneath.

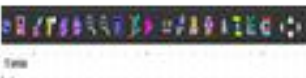

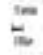

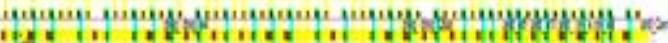

"is

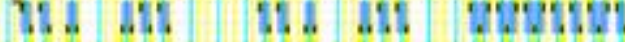

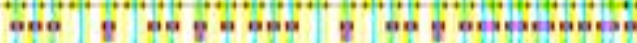

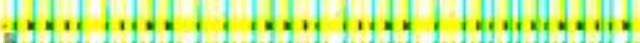

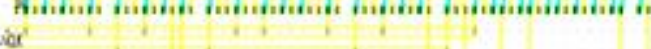

is

Module-3

Fig.6. Layout design of Module 1

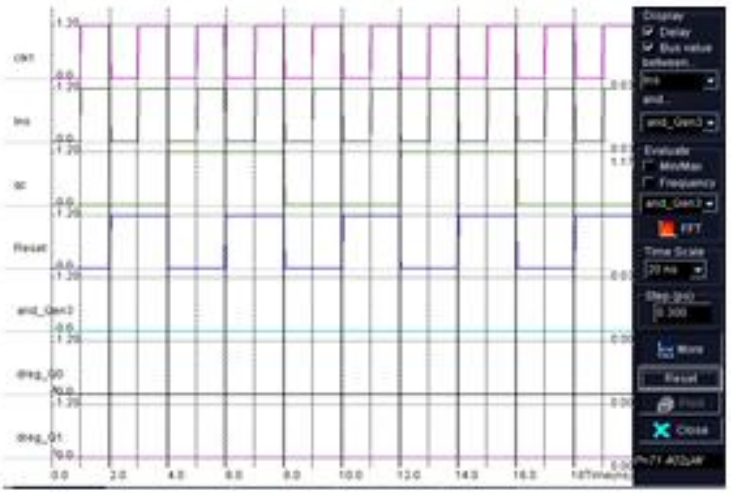

Fig.7. Simulation result for Module3Above figure, Portrays Module 3. It comprises of three yields Q1, Q0, and QEN3. Reset is handicap condition and INS is empower condition. Check will be begun because of the capacity of D-flip lemon. Utilizing Microwind, Simulation result for Module 3 as appeared in figure underneath [15
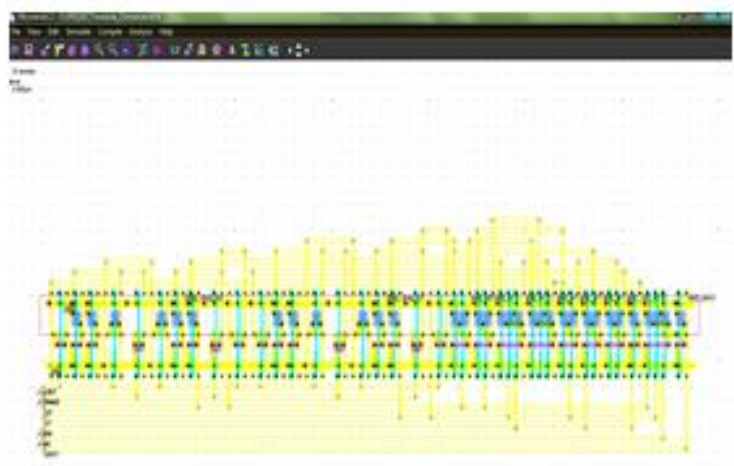

Fig.8. Layout design of Module3

Counter Path

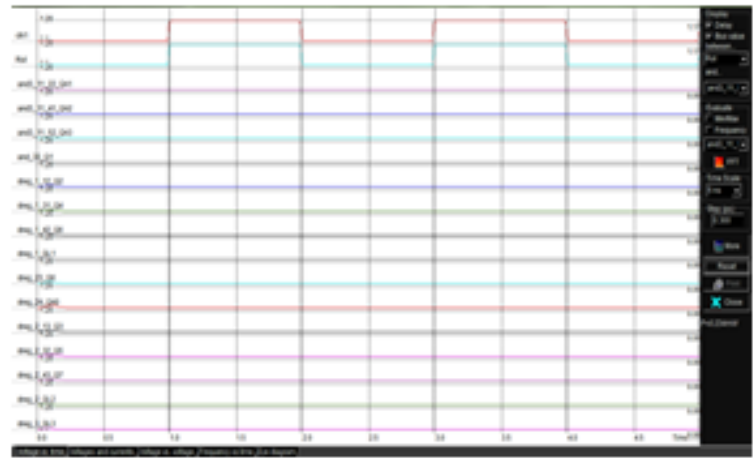

Fig.9. Simulation result for Counter Path

Above figure, portrays Counter way utilizing DSCH in Microwind instrument. Clock will be Triggered, Reset will be empower Condition. Yield is Q1-Q7, QA0-QA3, and QL1-QL3 [16]. 


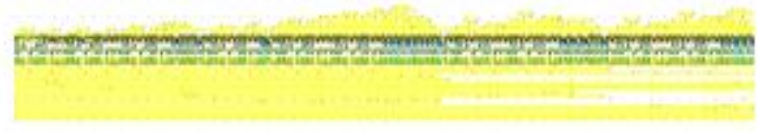

Fig.10. Layout design of Counter Path

\section{CONCLUSION}

The Proposed an adaptable fast parallel counter plan utilizing domino CMOS door rationale. The counter plan rationale is included just 2-bit checking modules AND. Counter way devour less power contrast and static CMOS rationale and working at rapid. At last, the counter way is getting the esteem $0.215 \mathrm{mw}$.

\section{REFERENCES}

1. Kongkham, D. \& Sundararajan, M. 2019, "Distributed wideband sensing method for faded dynamic spectrum access", International Journal of Innovative Technology and Exploring Engineering, vol. 8, no. 10, pp. 4309-4312.

2. Balaji, S., John Paul Praveen, A. \& Mohanraj, R. 2019, "Recognizable proof and analysis of palm print in biometric authentication system using bayes techniques", International Journal of Innovative Technology and Exploring Engineering, vol. 8, no. 9 Special Issue 3, pp. 1126-1129.

3. Kavitha, G., Priya, N., Velvizhi, R. \& Allin Geo, A.V. 2019, "Parallel computation in correspondence and signal processing", International Journal of Innovative Technology and Exploring Engineering, vol. 8, no. 9 Special Issue 3, pp. 1136-1139.

4. Hema, R., Sundararajan, M. \& Balaji, S. 2019, "Smartphone control robot with automatic firing gun", International Journal of Innovative Technology and Exploring Engineering, vol. 8, no. 9 Special Issue 3, pp. 625-627.

5. Kaliyamurthie, K.P., Sundar Raj, B., Velvizhi, R. \& Shanmugapriya, K. 2019, "Dual band paper substrate CPW antenna for wireless applications", International Journal of Innovative Technology and Exploring Engineering, vol. 8, no. 9 Special Issue 3, pp. 605-608.

6. Geo, A.V.A., Arunachalam, A.R., Michael, G. \& Elankavi, R. 2019 , "Evaluating architecture using compact modalities", International Journal of Innovative Technology and Exploring Engineering, vol. 8, no. 9 Special Issue 3, pp. 836-838

7. Theivasigamani, S., Jeyapriya, D. \& Anita Davamani, K. 2019, "Anamoly analyzing and exploring for wireless sensor networks", International Journal of Innovative Technology and Exploring Engineering, vol. 8, no. 9 Special Issue 3, pp. 1116-1118.

8. Jeyapriya, D., Theivasigamani, S., Velvizhi, R. \& Nandhini, P. 2019, "Program detection in wireless feeler networks", International Journal of Innovative Technology and Exploring Engineering, vol. 8, no. 9 Special Issue 3, pp. 1194-1195.

9. Gowri Sankaran, B., Karthik, B. \& Vijayaragavan, S.P. 2019, "Image compression utilizing wavelet transform", International Journal of Innovative Technology and Exploring Engineering, vol. 8, no. 10, pp. 4305-4308.

10. Gowri Sankaran, B., Karthik, B. \& Vijayaragavan, S.P. 2019, "Weight ward change region plummeting change for square based image huffman coding", International Journal of Innovative Technology and Exploring Engineering, vol. 8, no. 10, pp. 4313-4316.

11. Hema, R., Sundararajan, M. \& Balaji, S. 2019, "Smartphone control robot with automatic firing gun", International Journal of Innovative Technology and Exploring Engineering, vol. 8, no. 9 Special Issue 3, pp. 625-627.
12. Rangaswamy, K. \& Rajabhushanam, C. 2019, "Congestion control in wireless network using TCP friendly rate control (TFRC)", International Journal of Recent Technology and Engineering, vol. 8, no. 2 Special issue 3, pp. 1598-1602.

13. Tamil Selvan, S. \& Sundararajan, M. 2019, "Performance Parameters of 3 Value $8 \mathrm{t}$ Cntfet Based Sram Cell Design Using H-Spice", International Journal of Recent Technology and Engineering, vol. 8, no. 2 Special issue 5, pp. 22-27.

14. Vinoth, V.V. \& Kanniga, E. 2019, "Steganographical techniques in hiding text images - system", International Journal of Recent Technology and Engineering, vol. 8, no. 2, pp. 6535-6537.

15. Saravana, S., Balaji, S., Arulselvi, S. \& John Paul Praveen, A. 2019, "Reliable power quality monitoring and protection system", International Journal of Innovative Technology and Exploring Engineering, vol. 8, no. 9 Special Issue 3, pp. 644-645.

16. Sundaramoorthy, A. \& John Wiselin, M.C. 2019, "Single patch antenna with multiple feed", International Journal of Innovative Technology and Exploring Engineering, vol. 8, no. 9, pp. 1743-1747.

17. Velavan, R., Bharanidharan, S. \& Sheeba, B. 2019, "EMF pollution Causes, effects and protection", International Journal of Innovative Technology and Exploring Engineering, vol. 8, no. 9 Special Issue 3, pp. 1166-1168.

18. Veer, R.A., Arulselvi, S. \& Karthik, B. 2019, "Construction of ensemble square classification approaches in MIMO OFDM", International Journal of Engineering and Advanced Technology, vol. 8, no. 5, pp. 2039-2041.

19. Agitha, W. \& Kaliyamurthie, K.P. 2019, "Improved energy efficient in WBAN using MAC with cloud computing", International Journal of Innovative Technology and Exploring Engineering, vol. 8, no. 8, pp. 2405-2408.

20. Kastro, G.G. \& Wiselin, M.C.J. 2019, "Design and analysis of stub loaded resonator", International Journal of Recent Technology and Engineering, vol. 8, no. 1 Special Issue4, pp. 272-283.

\section{AUTHORS PROFILE}

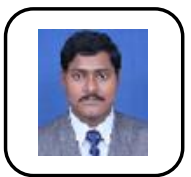

Mohan Raj.R Assistant Professor, Department of Electronics And Communication Engineering,., Bharath Institute of Higher Education and Research, Chennai, India..

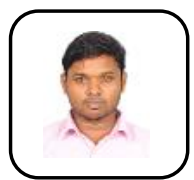

Balaji.S, Assistant Professor, Department of Electronics And Communication Engineering,, Bharath Institute of Higher Education and Research, Chennai, India.

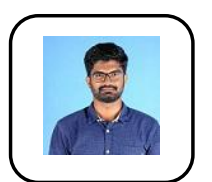

John Paul Praveen.A, Assistant Professor, Department of Electronics And Communication Engineering,, Bharath Institute of Higher Education and Research, Chennai, India.. 